\title{
Effect of 1-methylcyclopropene and ethylene on the physiology of peach fruits (Prunus persica L.) cv. Dorado during storage
}

\section{Efecto del 1-metilciclopropeno y el etileno en la fisiología de frutos de durazno (Prunus persica L.) cv. Dorado durante el almacenamiento}
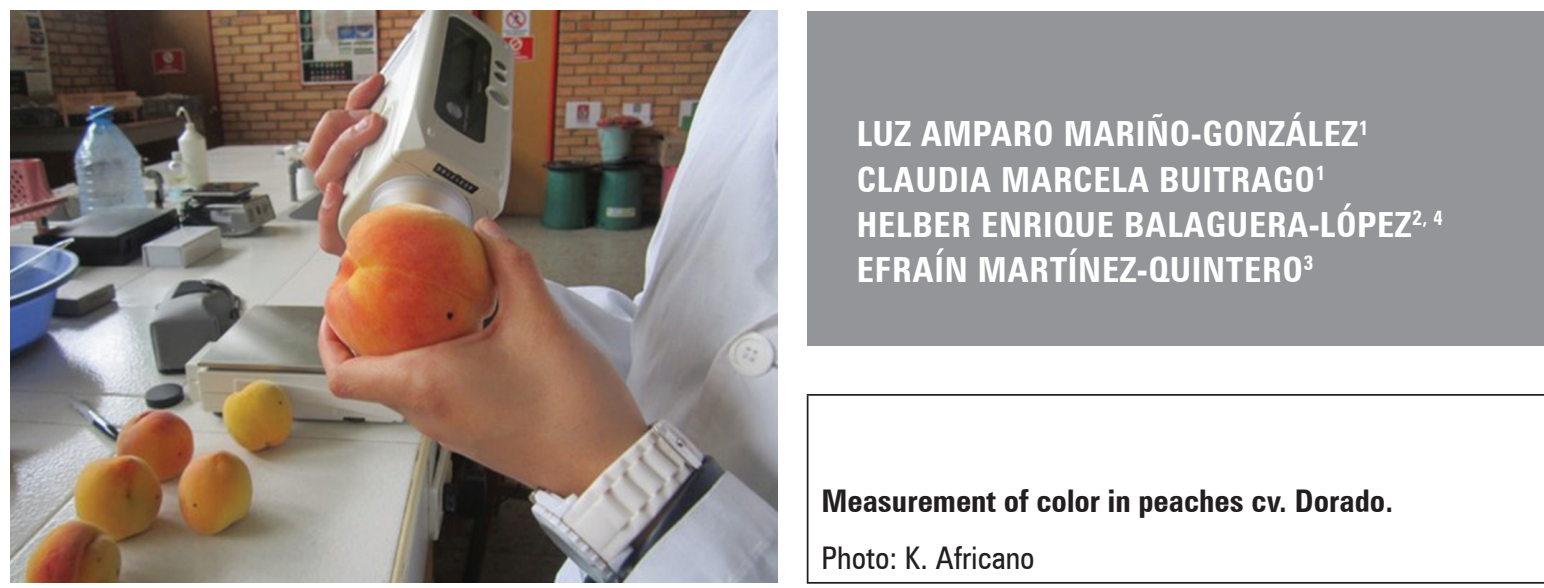

\section{ABSTRACT}

The peach (Prunus persica L., family Rosaceae) is a drupe that is consumed fresh and used in industry; it has a climacteric behavior and, because of its high water content, is highly perishable. This study aimed to evaluate the effect of 1-methylcyclopropene (1-MCP) and ethylene on the postharvest physiology of peach fruits cv. Dorado. Harvested fruits with 100\% green, $0 \%$ yellow skin color were used in a completely randomized design with four treatments: ethylene, 1-MCP, 1-MCP+ethylene and a control. After treatment, the fruits were stored at room temperature. During storage, the respiration rate, weight loss, firmness, color index of the skin, total soluble solids, total acidity and maturity ratio were evaluated. The results showed the efficiency of 1-MCP in peach cv. Dorado: 1-MCP decreased the respiration rate, color index of the skin, soluble solids and maturity ratio, while the firmness and total acidity were greater. The ethylene application showed an opposite effect, suggesting that it may regulate a large part of peach $\mathrm{cv}$. Dorado ripening.

\footnotetext{
Additional key words: postharvest technology; ripeners; plant growth substances; peach postharvest; stone fruits.

Universidad Pedagógica y Tecnológica de Colombia, Maestría en Fisiología Vegetal, Tunja (Colombia). ORCID MariñoGonzález, A.: 0000-0002-8545-505X, ORCID Buitrago, C.M.: 0000-0001-7730-0851

2 Universidad Pedagógica y Tecnológica de Colombia, Facultad de Ciencias Agropecuarias, Grupo de Investigaciones Agrícolas, Tunja (Colombia); Universidad El Bosque, Departamento de Biología, Bogota (Colombia). ORCID Balaguera-López, H.E.: 0000-0003-3133-0355

3 Universidad Pedagógica y Tecnológica de Colombia, Programa de Empresas Agropecuarias, Duitama (Colombia). ORCID Martínez-Quintero, E.: 0000-0001-8303-6284

4 Corresponding author. helber.balaguera@uptc.edu.co
} 


\section{RESUMEN}

El durazno (Prunus persica L., familia Rosaceae) es una drupa apetecida para consumo en fresco y la industrialización; presenta un comportamiento climatérico y tiene alto contenido de agua, por lo cual se considera un fruto altamente perecedero. El objetivo de este estudio fue evaluar el efecto del uso de 1-metilciclopropeno (1-MCP) y etileno sobre la fisiología poscosecha de frutos de durazno, cv. Dorado. Se utilizaron frutos cosechados con color de la epidermis $100 \%$ verde, $0 \%$ amarillo, se dispusieron en un diseño completamente al azar con cuatro tratamientos que correspondieron a etileno, 1-MCP, 1-MCP + etileno y un control sin aplicación. Luego del tratamiento, los frutos fueron almacenados a temperatura ambiente. Durante el almacenamiento se evaluó la tasa respiratoria, pérdida de peso, índice de color de la epidermis, firmeza, sólidos solubles, acidez total y relación de madurez. Los resultados mostraron la eficiencia de la aplicación de 1-MCP en durazno cv. Dorado, ya que generó significativamente menor tasa de respiración, índice de color de la epidermis, sólidos solubles y relación de madurez, mientras que la acidez total y firmeza fueron mayores. Por su parte, la aplicación de etileno mostró el efecto contrario en estos procesos, indicando que al parecer regula gran parte del proceso de maduración del fruto de durazno cv. Dorado.

Palabras clave adicionales: tecnología poscosecha; maduradores; sustancias de crecimiento vegetal; frutos de hueso.

Received for publication: 26-10-2018 Accepted for publication: 29-03-2019
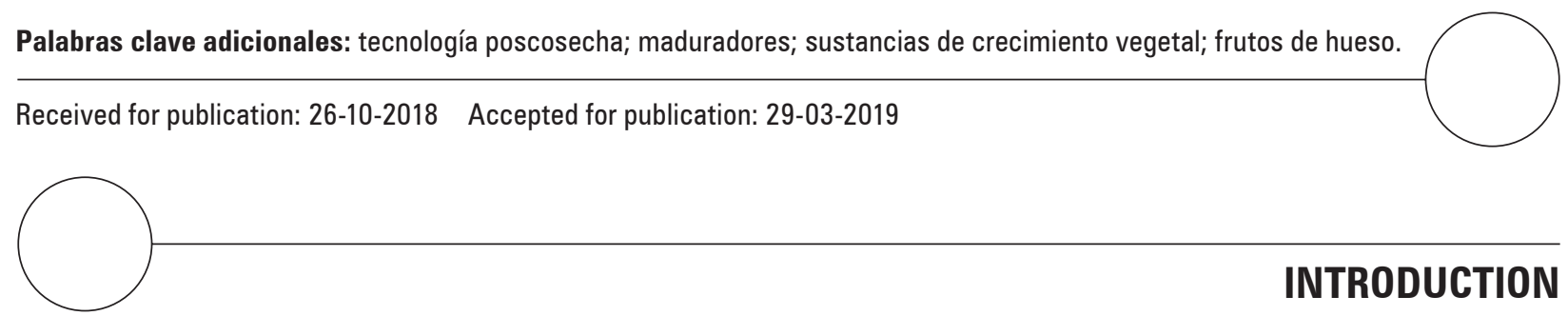

INTRODUCTION

The peach (Prunus persica L.) cv. Dorado is characterized by a yellow epidermis, with a light red pigmentation, gold-yellow mesocarp with red colorations around the endocarp, trichomes on the exocarp, velvety skin, and mesocarp adnate to the endocarp; additionally, it has a high sugar content and can reach up to $150 \mathrm{~g}$ in weight. All of these characteristics make the peach highly desirable for fresh consumption and for industrialization (Campos, 2013). Of the deciduous fruit trees, the peach is very important for Colombian agriculture, particularly in the Department of Boyaca because of its optimal edaphoclimatic characteristics, vocation and productive expertise (Puentes et al., 2015). However, the peach cv. Dorado is highly perishable and has a short postharvest life (11 $\mathrm{d}$ in the conditions evaluated by Africano et al., 2016), which limits its commercialization. This may be due to the fact that the peach is a climacteric fruit (Africano et al., 2016), which means there is an accelerated increase in the ethylene production and the respiratory rate associated with ripening (Brackmann et al., 2013).

Ethylene is the hormone responsible for triggering physiological, biochemical and molecular processes that guarantee fruit ripening (Binder, 2008; Balaguera-López et al., 2014a) by bonding to a group of protein receptors mainly located on the membrane of the endoplasmic reticulum (Chen et al., 2005; Serek et al., 2006). Ethylene allows fruits to reach optimal organoleptic characteristics for consumption; however, it is also in charge of inducing senescence, which causes agricultural products to loose nutritional and commercial value (Bapat et al., 2010; Balaguera-López et al., 2014a).

To reduce the postharvest losses of the peach cv. Dorado, it is necessary to understand the processes associated with ethylene during ripening, as a foundation for various technologies that reduce the biosynthesis and action of ethylene. Zhang et al. (2012) stated that the ethylene regulation of peach ripening has been thoroughly studied using biochemical, molecular and genetic techniques. However, several reviews on ethylene biosynthesis suggest that the exact role of ethylene in the ripening process is not yet fully understood (Bapat et al., 2010; Barry and Giovannoni, 2007) and that the knowledge gap is even greater in peach genotypes grown in the high tropics. In this regard, several studies have used the application of ethylene and 1-methylcyclopropene (1-MCP) on fruit (Zhang et al., 2012; Yang et al., 2013; Balaguera-López et al., 2016; Barreto et al., 2017).

1-MCP is the main ethylene inhibitor (Watkins, 2006), taking up the place of the ethylene receptors irreversibly and, thus, blocking the transduction chain of the signals responsible for the genetic expression related to the response to this hormone (In et al., 2013). The effect of 1-MCP on the physiological and biochemical 
processes of peach ripening has been evaluated in several studies with conflicting results: in some studies, 1-MCP blocked ethylene biosynthesis, but in others, it was ineffective (Dal Cin et al., 2006; Hayama et al., 2008; Tadiello et al., 2016; Wang et al., 2017). Liu et al. (2005, 2015) and Wang et al. (2017) found that 1-MCP delayed peach fruit ripening. However, Kluge and Jacomino (2002) and Tonetto et al. (2007), among others, suggested that the utility of $1-\mathrm{MCP}$ is limited because it can delay peach ripening only when it is applied during the pre-climacteric state. Therefore, this study aimed to evaluate the effect of 1-MCP and ethylene, both individually and combined, on the postharvest behavior of the peach fruit cv. Dorado in order to understand ethylene-dependent ripening and the commercial potential of 1-MCP for extending the postharvest life and commercial period of this fruit.

\section{MATERIAL AND METHODS}

The peach (Prunus persica L.) cv. Dorado fruits came from a peach commercial crop located in Cerinza, Boyaca. The fruits were harvested with $100 \%$ green epidermis $-0 \%$ yellow-red, with color values $L^{*}=62.54$, $a=-4.58$ and $b=40.81$. They had a homogeneous size and good phytosanitary conditions and were taken to the postharvest laboratory of the Universidad Pedagógica y Tecnológica de Colombia (UPTC), Duitama campus, where the experiments were conducted.

Four treatments in a completely random experiment design were evaluated: 1-MCP, 1-MCP+ethylene, ethylene and a control; each treatment was replicated four times, for a total of 16 experiment units, each one composed of approximately $1,000 \mathrm{~g}$ of fruit. One day after harvest, the fruits were washed and disinfected with a $1 \%$ sodium hypochlorite solution, and the treatments were immediately applied. For the 1-MCP (EthylBloc ${ }^{\circledR}$ ) treatment, a $0.35 \mathrm{mg} \mathrm{L}^{-1} 1$-MCP solution was used, in which the fruits were submerged for 5 min, the adapted methodology of Choi et al. (2008). For the ethylene treatment, fruits were submerged in $1000 \mathrm{mg} \mathrm{L}^{-1}$ of ethephon (Ethrel® 48 SL, Bayer CropScience) for $5 \mathrm{~min}$ and dried at room temperature; for the 1-MCP+Ethylene treatment, the ethylene was applied $7 \mathrm{~d}$ after the 1-MCP application. Finally, the fruits were stored on trays of expanded polystyrene at room temperature $\left(16 \pm 2^{\circ} \mathrm{C}\right.$; relative humidity of $70 \pm 12 \%$ at average). The variables were measured at $1,4,7,12,16$ and 19 days of storage (DOS), until the fruits lost their commercial quality. The respiratory rate (RR; mg CO $\mathrm{kg}^{-1} \mathrm{~h}^{-1}$ ) was estimated by taking
$600 \mathrm{~g}$ of fruit approximately and placing them in VER BC-2000 $2000 \mathrm{~cm}^{3}$ hermetic chambers (Vernier Software \& Technology, Beaverton, OR) for $5 \mathrm{~min}$ and by determining the concentration of $\mathrm{CO}_{2}$ with a VER $\mathrm{CO}_{2}$-BTA sensor and the LabQuest2 interface system (Vernier Software \& Technology, Beaverton, OR). The weight loss was calculated by measuring the fresh mass (the same fruits used for RR) in an Acculab VIC 612 electronic scale, $0.01 \mathrm{~g}$ precision (Sartorius Spain S.A., Madrid). To determine the color index (CI), the equation (1) reported by Balaguera-López et al. (2014a) was used; the system parameters, CIELab "L", "a" and " $b$ ", were obtained from three readings in the equatorial zone of two fruits per replication, using a Minolta CR 300 digital colorimeter (Minolta Co., Tokyo).

$$
\mathrm{IC}=\left(1000 \times \mathrm{a}^{*}\right) /\left(\mathrm{L}^{*} \times \mathrm{b}^{*}\right)
$$

The fruit firmness was estimated using a PCEPTR200 digital penetrometer (PCE-Ibérica SL, Albacete, Spain) with $0.05 \mathrm{~N}$ approximation, and the soluble solids (SS) were measured using a Hanna HI 96803 digital refractometer (Hanna Instruments, Woonsocket, RI) with a $0-85 \%$ range and $0.1{ }^{\circ}$ Brix precision. For the total acidity (TA), which was expressed as the percentage of malic acid, the volume data of $\mathrm{NaOH}$, using $1 \mathrm{~g}$ of fruit juice, taken to $25 \mathrm{~mL}$ with distilled water, and adding two drops of phenolphthalein in a base-acid titration, were used. The maturity ratio (MR) was determined as the quotient between SS and TA. For the destructive measurements (firmness, SS, TA, MR), one fruit was used in each sample for experimental unity.

The obtained data were analyzed with normality (Shapiro-Wilk) and homogeneity (Levene test) tests; subsequently, an analysis of variance and a Tukey range test $(P \leq 0.05)$ were conducted; the statistics software R v 3.4.2 was used.

\section{RESULTS AND DISCUSSION}

All sampling points showed statistically significant differences $(P \leq 0.05)$ in the respiration rate; the treatment that resulted in the highest respiratory rate was ethylene, followed by the control, although they were not significantly different. These two treatments were significantly different from the treatments with 1-MCP. Additionally, the treatment with ethylene and the control increased the respiration rate notably after $12 \mathrm{~d}$ of storage, reaching values of 60.89 and 
$59.01 \mathrm{mg} \mathrm{CO}_{2} \mathrm{~kg}^{-1} \mathrm{~h}^{-1}$, respectively. On the contrary, the application of 1-MCP resulted in a smaller respiration rate over the storage period, showing a prolong increase from day 7 to 19 , with a value of $50.13 \mathrm{mg}$ $\mathrm{CO}_{2} \mathrm{~kg}^{-1} \mathrm{~h}^{-1}$; this result was similar to that observed in the fruits treated with 1-MCP+ethylene (Fig. 1).

The respiratory rate in climacteric fruits, including peach, depends on ethylene. Zhang et al. (2012) found that ethephon can accelerate energy production, glycolytic metabolism and ethylene biosynthesis, which may accelerate respiration in the tissue. In apple fruits, Yang et al. (2013) noted that the application of ethylene increased the respiratory rate, whereas 1-MCP decreased it, similar to that observed in this research.

The results showed that the application of 1-MCP decreased the respiration rate, perhaps because it blocks ethylene cellular receptors (Watkins, 2006). Similar studies have suggested that peach fruits reduce their respiratory rate in the presence of 1-MCP, thus, decreasing the intensity of physiological processes (Steffens et al., 2009; Wang et al., 2017). Likewise, Valero et al. (2004) showed that applications of 1-MCP delayed the climacteric increase in plums, whereas treatments with ethylene accelerated it. Therefore, the respiratory rate is closely related to the climacteric rate; hence, the application of 1-MCP is a

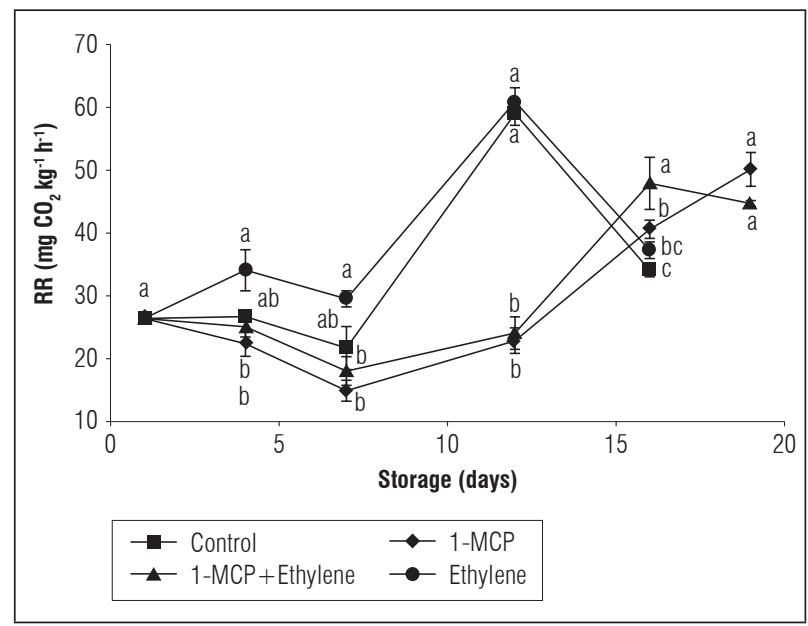

Figure 1. Effect of ethylene and 1-methylcyclopropene on respiratory rates (RR) of peach cv. Dorado fruits during storage. Means followed by different letters on the same sampling day showed statistically significant differences according to Tukey's test $(P \leq 0.05)$. Vertical bars on each mean indicate the standard error $(n=4)$. viable alternative to prolong peach fruit quality. On the other hand, the increase in the respiratory rate shown by the fruits treated with 1-MCP may have been due to a rise in the amount of ethylene receptors synthetized by the tissue (Serek et al., 2006). Despite this, the addition of ethylene after 1-MCP did not increase the respiration, as compared to the fruits treated with 1-MCP, possibly because the low levels of ethylene in the tissues were sufficient to bind to the few existing receptors (through the effect of the $1-\mathrm{MCP}$ ) and induce an increase in the respiratory rate of the peach fruits.

For firmness, the peach cv. Dorado fruits showed a constant decrease in firmness during storage, which agrees with Africano et al. (2016) for the same cultivar. Statistically significant differences $(P \leq 0.05)$ were observed starting at $7 \mathrm{DOS}$, when the fruits treated with 1-MCP had the highest firmness, and the fruits treated with ethylene had the lowest. The control fruits did not have differences from those treated with ethylene; the fruits under these two treatments lost their organoleptic quality at $16 \mathrm{DOS}$, showing a final firmness of $25.2 \pm 2.95 \mathrm{~N}$ for the control and $22.23 \pm 2.06 \mathrm{~N}$ for the ethylene treatment; the fruits treated with 1-MCP+ethylene became soft rapidly toward the end of the storage period (Fig. 2).

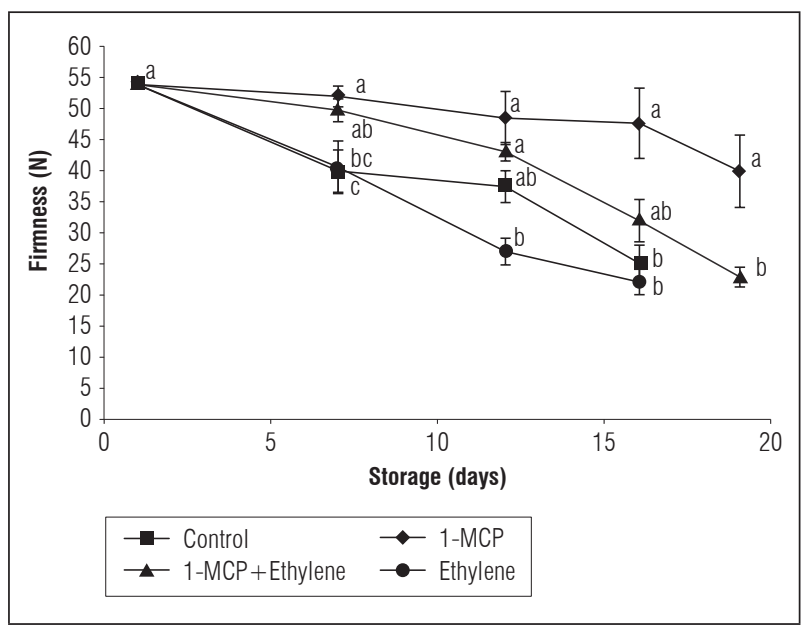

Figure 2. Effect of ethylene and 1-methylcyclopropene on the firmness of peach cv. Dorado fruits during storage. Means followed by different letters on the same sampling day showed statistically significant differences according to Tukey's test $(P \leq 0.05)$. Vertical bars on each mean indicate the standard error $(n=4)$. 
The loss of firmness in a fruit may be related to an increase in the activity of enzymes that degrade the cell wall in peaches, such as polygalacturonase, pectin-methylesterase, endo- $\beta-1,4$-glucanase, $\alpha$-arabinosidase and $\beta$-galactosidase. The activity of these enzymes may increase in the presence of ethylene because the depolymerization of pectins and xyloglucans is regulated by ethylene (Nishiyama et al., 2007; Pech et al., 2008) and it is expected to decrease as a result of the effect of 1-MCP, which blocks ethylene activity at the cellular level; this suggests that, in peach cv. Dorado fruits, firmness may also be regulated by ethylene, even after the application of 1-MCP. Özkaya et al. (2016) found a reduction in the activity of pectin methyl esterase and polygalacturonase in apricot fruits. Liu et al. (2015), in peach cv. Yahuala, and Wang et al. (2017), in peach cv. CN13, found that the application of 1-MCP increased firmness in comparison with non-treated fruits. Similarly, Khan and Singh (2007) found that 1-MCP delayed the loss of firmness in Prunus salicilina Lindl fruits by reducing the activity of polygalacturonase, pectin esterase and endo-1,4-d-glucanase, whereas Zhang et al. (2012), when using proteomics on peach fruits, found that 1-MCP decreased the loss of $\mathrm{Ca}$ ions, suppressed the degradation of the cell wall and maintained the mechanical properties of the cellular structure.

The color index (CI) of the skin increased with storage time. There were significant differences $(P \leq 0.05)$ between all treatments starting at day seven of storage. The changes were smaller in the fruits treated with 1-MCP $(P \leq 0.05)$, showing a CI of $2.63 \pm 0.59$ at the end of the storage period. The fruits treated with ethylene showed a higher index color $(3.87 \pm 0.48)$, despite the use of ethylene $7 \mathrm{~d}$ after 1-MCP; the control treatment showed a CI increase during storage (Fig. 3). Lelievre et al. (1997) stated that color changes may be dependent or independent of ethylene, as was later suggested by Dong et al. (2002), who observed changes in color independent of ethylene in Prunus armeniaca. However, these studies indicated that color in the peach cv. Dorado is dependent on ethylene; in fact, Barreto et al. (2017) found that, by applying ethylene to 'Chiripá' peach fruits, the color changed more than when applying 1-MCP.

The lower CI that resulted from the application of 1-MCP in the peach fruits may have been due to the fact that this compound delays color change since it can decrease chlorophyll degradation by reducing the activity of the chlorophyllase enzyme (Watkins, 2006; Sun et al., 2012), which is up-regulated by ethylene.
Likewise, 1-MCP also decreased color changes in the peach cv. Aurora-1 (Kluge and Jacomino, 2002) and in the peach 'Roubidoux' (Steffen et al., 2009).

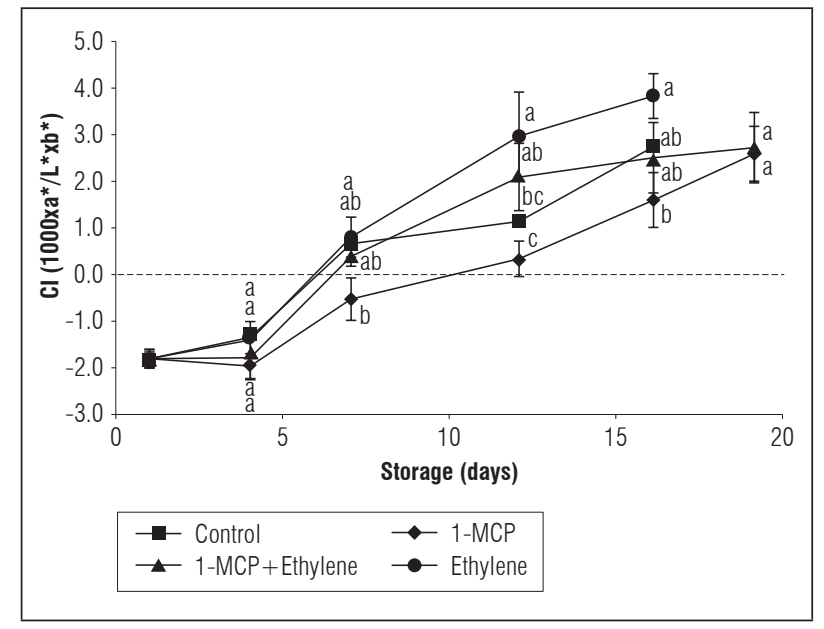

Figure 3. Effect of ethylene and 1-methylcyclopropene on color index (CI) of peach cv. Dorado fruits during storage. Means followed by different letters on the same sampling day showed statistically significant differences according to Tukey's test $(P \leq 0.05)$. Vertical bars on each mean indicate the standard error $(n=4)$.

The soluble solids (SS) increased gradually with storage. There were significant differences $(P \leq 0.05)$ between all sampling points. The fruits treated with 1-MCP accumulated less SS in every measurement, showing a value of $13.7 \pm 0.21^{\circ} \mathrm{Brix}$ at the end of storage, whereas the fruits treated with ethylene, alone or in combination with 1-MCP, showed a higher concentration of SS (16.1 $\pm 0.35^{\circ}$ Brix; Fig. 4).

The higher concentration of SS at the end of storage may be explained by the hydrolysis of starch and polysaccharides in the cell wall (Kays and Paull, 2004); in peach cv. Dorado fruits, ethylene may play a role in accelerating hydrolysis processes, while 1-MCP may delay them, which supports the hypothesis that ethylene regulates a large part of peach fruit ripening in cv. Dorado. Likewise, Zhang et al. (2012) found that, in peach cv. Huiyulu, 1-MCP decreased starch degradation, decreasing the glycolytic metabolism and, therefore, ripening.

Our results agree with Barreto et al. (2017) who, in peach cv. Chiripá, found lower SS values for fruits treated with 1-MCP than for fruit treated with ethylene; on the contrary, Tonetto et al. (2007) and 
Steffens et al. (2009) did not observe any effect on SS after applying 1-MCP in the peaches 'Eldorado' and 'Roubidoux'.

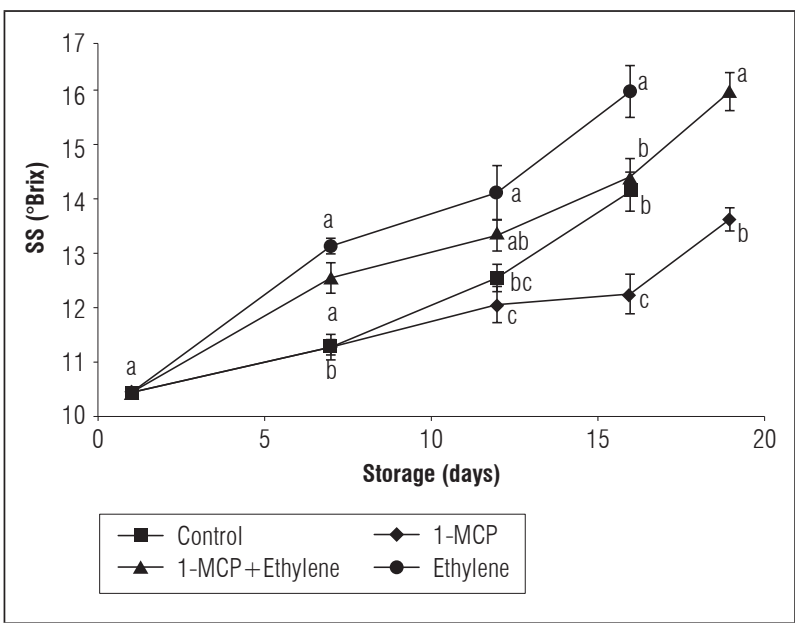

Figure 4. Effect of ethylene and 1-methylcyclopropene on soluble solids (SS) of peach cv. Dorado fruits during storage. Means followed by different letters on the same sampling day showed statistically significant differences according to Tukey's test $(P \leq 0.05)$. Vertical bars on each mean indicate the standard error $(n=4)$.

The total acidity (TA) showed statistically significant differences $(P \leq 0.05)$ between all sampling points during storage, except at 19 DOS. For all treatments, there was a gradual decrease in acidity, which was higher for the ethylene and control treatments and lower for the 1-MCP treatment; at $19 \mathrm{DOS}$, the fruits with 1-MCP showed $0.95 \pm 0.11 \%$ TA (Fig. 5).

According to Alves et al. (2009), the effect of 1-MCP on the TA of peach fruits may be explained by a lower acid consumption during the tricarboxylic acid cycle through the reduction of respiration. As observed in this study, TA decreases over the storage period because organic acids are part of the respiration substrates (Kays and Paull, 2004). Similar results have been shown by Barreto et al. (2017) in the peach, who found higher acidity in fruits treated with 1-MCP than in fruits treated with ethylene, which accelerates the loss of TA. Liu et al. (2015) also observed a higher TA with 1-MCP in peaches. On the contrary, Tonetto et al. (2007) did not observe effects from 1-MCP on the TA of the peach 'Eldorado', similar to Steffens et al. (2009) for the peach cv. Roubidoux. This suggests that the effect of 1-MCP on acidity depends on the cultivar, as indicated by Ligouri et al. (2004).

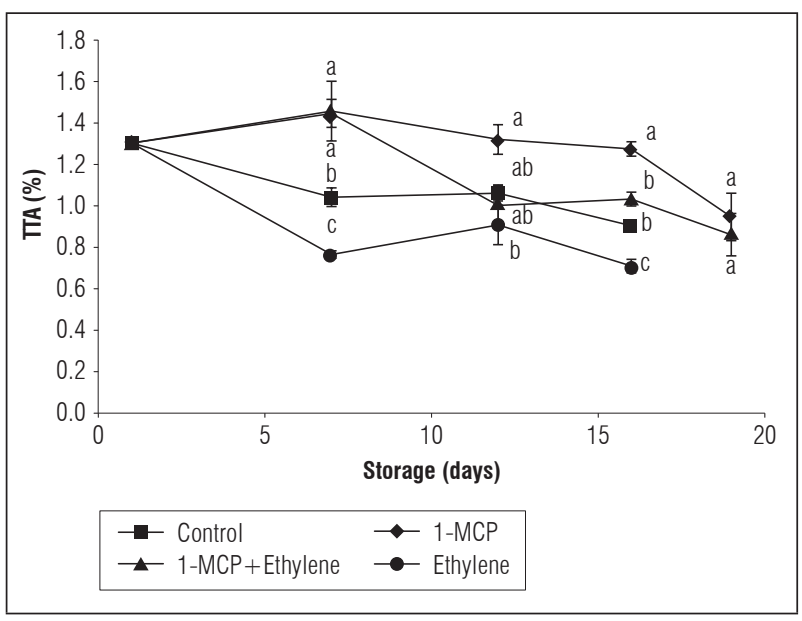

Figure 5. Effect of ethylene and 1-methylcyclopropene on total titratable acidity (TTA) of peach cv. Dorado fruits during storage. Means followed by different letters on the same sampling day showed statistically significant differences according to Tukey's test $(P \leq 0.05)$. Vertical bars on each mean indicate the standard error $(n=4)$.

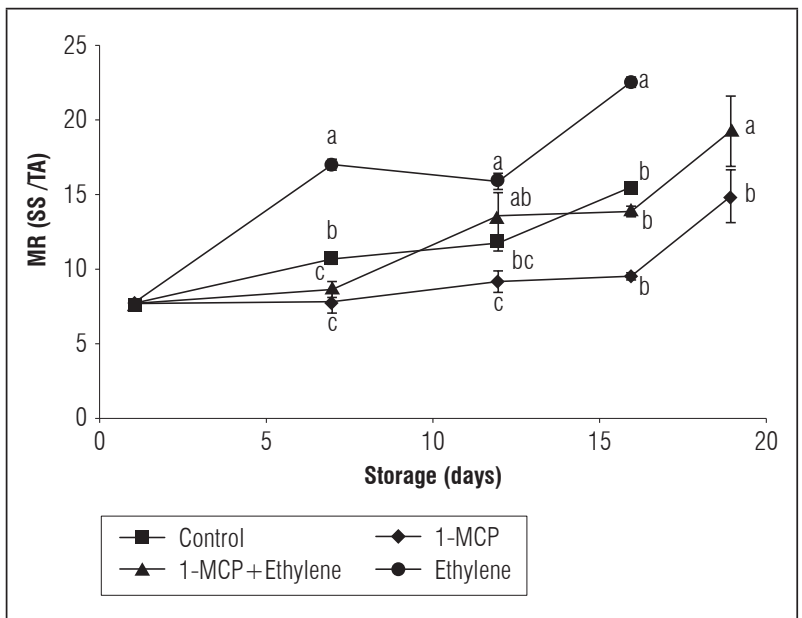

Figure 6. Effect of ethylene and 1-methylcyclopropene on maturity ratio (MR) of peach cv. Dorado fruits during storage. Means followed by different letters on the same sampling day showed statistically significant differences according to Tukey's test $(P \leq 0.05)$. Vertical bars on each mean indicate the standard error $(n=4)$.

The maturity ratio (MR) increased gradually throughout storage and showed significant differences $(P \leq 0.05)$ between the treatments in all sampling points. The lowest values were found in the fruits treated with 1-MCP and with 1-MCP+ethylene, indicating a delay in MR (Fig. 6). The fruits treated 
with ethylene ripened faster, showing higher MR values over the storage period, which is a typical behavior for this variable, perhaps because of the increase in SS and decrease in TA (Ferrer et al., 2005; Africano et al., 2015). Accordingly, the exogenous application of ethylene accelerates ripening in peach cv. Dorado fruits, whereas 1-MCP delays it; however, Tonnetto et al. (2007) did not find any effect from 1-MCP on the MR of the peach 'Eldorado'.

\section{CONCLUSIONS}

Our results suggest that $1-\mathrm{MCP}$ decreases the respiration rate, loss of firmness, epidermis color index, total soluble solids, total titratable acidity, and maturity ratio in the peach cv. Dorado, whereas ethylene has an opposite effect. Our results demonstrate that several ripening processes in peach cv. Dorado fruits are associated with the presence of ethylene and that 1-MCP may delay ripening throughout the storage of this fruit.

\section{ACKNOWLEDGMENTS}

The authors wish to thank the "Dirección de Investigaciones, Universidad Pedagógica y Tecnológica de Colombia (UPTC), Tunja, Colombia" for supporting this study.

Conflict of interests: this manuscript was prepared and reviewed with the participation of the authors, who declare that there exists no conflict of interest that puts the validity of the presented results at risk.

\section{BIBLIOGRAPHIC REFERENCES}

Africano, K., P. Almanza-Merchán, H. Criollo, A. Herrera, and H.E. Balaguera-López. 2016. Caracterización poscosecha del fruto de durazno [Prunus persica (L.) Batsch] cv. Dorado producido bajo condiciones de trópico alto. Rev. Colomb. Cienc. Hortic. 10(2), 232-240. Doi: 10.17584/rcch.2016v10i2.5212

Africano, K., H.E. Balaguera-López, and P. Almanza-Merchán. 2015. Fisiología y bioquímica de la maduración del fruto de durazno [Prunus persica (L.) Batsch]. Una Revisión. Rev. Colomb. Cienc. Hortic. 9 (1), 161-172. Doi: 10.17584/rcch.2015v9i1.3754

Alves, E.O., C.A. Steffens, C.V.T. Amarante, A. Weber, A. Miqueloto, and A. Brackmann. 2009. Armazenamento refrigerado de ameixas. Laetitia. com uso de 1-MCP e indução de perda de massa fresca. Ciênc. Rural 40, 30-36. Doi: 10.1590/S0103-84782009005000251
Balaguera-López, H.E., M. Espinal-Ruiz, L. Zacarías, and A. Herrera. 2016. Effect of ethylene and 1-methylcyclopropene on the postharvest behavior of cape gooseberry fruits (Physalis peruviana L.). Food Sci. Technol. Int. 23(1), 86-96. Doi: 10.1177/1082013216658581

Balaguera-López, H.E., C. Martínez, and A. Arévalo. 2014a. Papel del cáliz en el comportamiento poscosecha de frutos de uchuva (Physalis peruviana L.) ecotipo Colombia. Rev. Colomb. Cienc. Hortic. 8(2), 181-191. Doi: 10.17584/rcch.2014v8i2.3212

Balaguera-López, H.E., F. Salamanca-Gutiérrez, J.C. García, and A. Herrera. 2014b. Etileno y retardantes de la maduración en la poscosecha de productos agrícolas. Una revisión. Rev. Colomb. Cienc. Hortic. 8, 302-313. Doi: 10.17584/rcch.2014v8i2.3222

Bapat, V.A., P.K. Trivedi, A. Ghosh, V.A. Sane, T.R. Ganapathi, and P. Nath. 2010. Ripening of fleshy fruit: Molecular insight and the role of ethylene. Biotechnol. Adv. 28, 94-107. Doi: 10.1016/j.biotechadv.2009.10.002

Barreto, C.F., R.R. Zandoná, G. Acorsi, A. Copatti, and J. Saavedra. 2017. Efeito do 1-Metilciclopropeno na qualidade pós-colheita de pessegos 'Chiripá'. Rev. Iberoam. Tecnol. Postcos. 18(1), 33-38.

Barry, C.S. and J.J. Giovannoni. 2007. Ethylene and fruit ripening. J. Plant Reg. 26(2), 143-159. Doi: 10.1007/ s00344-007-9002-y

Binder, B.M. 2008. The ethylene receptors: complex perception for a simple gas. Plant Sci. 175, 8-17. Doi: 10.1016/j.plantsci.2007.12.001

Brackmann, A., V. Both, E.P. Pavanello, R.O. Anese, and J.R.S. Santos. 2013. Controlled atmosphere, ethylene absorption and 1-MCP application during storage of 'Eragil' peaches. Científica 41, 156-163. Doi: 10.1590/ S0103-84782004000500014

Campos, T. 2013. Especies y variedades de hoja caduca en Colombia. pp. 47-56. En: Miranda, D., G. Fischer, and C. Carranza (eds.). Los frutales caducifolios en Colombia: situación actual, sistemas de cultivo y plan de desarrollo. Sociedad Colombiana de Ciencias Hortícolas, Bogota.

Chen, Y., N. Etheridge, and E. Schaler. 2005. Ethylene signal transduction. Ann. Bot. 95, 901-915. Doi: 10.1093/ aob/mci100

Choi, S., P. Tsouvaltzis, Ch. Lim, and D.J. Huber. 2008. Suppression of ripening and induction of asynchronous ripening in tomato and avocado fruits subjected to complete or partial exposure to aqueous solutions of 1-methylcyclopropene Postharvest Biol. Technol. 48, 206-214. Doi: 10.1016/j.postharvbio.2007.10.008

Dal Cin, V., F.M. Rizzini, A. Botton, and P. Tonutti. 2006. The ethylene biosynthetic and transduction pathways are differently affected y 1-MCP in apple and peach fruit. Postharvest Biol. Technol. 42, 125-133. Doi: 10.1016/j.postharvbio.2006.06.008 
Dong, L., S. Lurie, and H.W. Zhou. 2002. Effect of 1-metylcyclopropene on ripening of 'Canino' apricots and Royal Zee plums. Postharvest Biol. Tecnol. 24, 135-145. Doi: 10.1016/S0925-5214(01)00130-2

Ferrer, A., S. Remón, A. Negueruela, and R. Oria. 2005. Changes during the ripening of the very late season Spanish peach cultivar Calanda: Feasibility of using CIELAB coordinates as maturity indices. Sci. Hortic. 105(4), 435-446. Doi: 10.1016/j.scienta.2005.02.002

Hayama, H., M. Tatsuki, and Y. Nakamura. 2008. Combined treatment of aminoethoxyvinylglycine (AVG) and 1-methylcyclopropene (1-MCP) reduces peach fruit softening. Postharvest Biol. Technol. 50(2), 228230. Doi: $10.1016 /$ j.postharvbio.2008.05.003

In, B.C., J. Strablea, B.M. Binder, T.G. Falbel, and S.E. Patterson. 2013. Morphological and molecular characterization of ethylene binding inhibition in carnations. Postharv. Biol. Technol. 86, 272-279. Doi: 10.1016/j. postharvbio.2013.07.007

Kays, S.J. and R.E. Paull. 2004. Postharvest biology. Exon Press, Athens, GA.

Khan, A. and Z. Singh. 2007. 1-MCP regulates ethylene biosynthesis and fruit softening during ripening of 'Tegan Blue' plum. Postharvest Biol. Technol. 43, 298306. Doi: 10.1016/j.postharvbio.2006.10.005

Kluge, R. and A. Jacomino. 2002. Shelf life of peaches treated whit 1-methylcyclopropene. Sci. Agric. 59(1), 6972. Doi: 10.1590/S0103-90162002000100010

Lelievre, J.M., L. Tichit, P. Dao, L. Fillion, Y.W. Nam, J.C. Pech, and A. Latche. 1997. Effects of chilling on the expression of ethylene biosynthetic genes in Passe-Crassane pear (Pyrus communis L.) fruits. Plant Mol. Biol. 33, 847-855. Doi: 10.1111/j.1399-3054.1997.tb01057.x

Ligouri, G., A. Wekslerb, Y. Zutahib, S. Lurieb, and I. Kostoc. 2004. Effect of 1-Methylcyclopropene on ripening of melting flesh peaches and nectarines. Postharvest Biol. Technol. 31, 263-268. Doi: 10.1016/j. postharvbio.2003.09.007

Liu, H., J. Cao, and W. Jiang. 2015. Changes in phenolics and antioxidant property of peach fruit during ripening and responses to 1-methylcyclopropene. Postharvest Biol. Technol. 108, 111-118. Doi: 10.1016/j. postharvbio.2015.06.012

Liu, H., W. Jiang, L. Zhou, B. Wang, and Y. Luo. 2005. The effects of 1- methylcyclopropene on peach fruit (Prunus persica L. cv. Jiubao) ripening and disease resistance. Int. J. Food Sci. Technol. 40, 1-7. Doi: 10.1111/j.1365-2621.2004.00905.x

Nishiyama, K., M. Guis, J.K.C. Rose, Y. Kubo, K.A. Bennett, and L. Wangjin. 2007. Ethylene regulation of fruit softening and cell wall disassembly in Charentais melon. J. Exp. Bot. 58, 1281-1290. Doi: 10.1093/jxb/erl283
Özkaya, O., D. Yildirim, Ö. Dündar, and S. Seyhan. 2016. Effects of 1-methylcyclopropene (1-MCP) and modified atmospherepackaging on postharvest storage quality of nectarine fruit. Sci. Hort. 198, 454-461. Doi: 10.1016/j.scienta.2015.12.016

Pech, J.C., M. Bouzayen, and A. Latche. 2008. Climacteric fruit ripening: ethylene-dependent and independent regulation of ripening pathways in melon fruit. Plant Sci. 175, 114-120. Doi: 10.1016/j.plantsci.2008.01.003

Puentes, G.A., L.A. Bastidas, and A.J. Lemus. 2015. Estimación de pérdidas técnicas y financieras en cosecha de durazno, en la granja Tunguavita de la UPTC, Boyacá. Rev. Agron. 23(1), 93-105.

Serek, M., E.J. Woltering, E.C. Sisler, S. Frello, and S. Sriskandarajah. 2006. Controlling ethylene responses in flowers at the receptor level. Biotechnol. Adv. 24, 368381. Doi: 10.1016/j.biotechadv.2006.01.007

Steffens, C.A., C.V.T. Amarante, J.P.G. Silveira, B.P. Espindola, M.V. Hendges, and A. Brackmann. 2009. Amadurecimento de pêssegos 'Rubidoux' em resposta à presença de pressões parciais de $\mathrm{CO}_{2}$ durante o tratamento com 1-MCP. Ciênc. Rural 39, 2361-2366. Doi: 10.1590/S0103-84782009000800014

Sun, B., H. Yan, N. Liu, J. Wei, and O. Wang. 2012. Effect of 1-MCP treatment on postharvest quality characters, antioxidants and glucosinolates of chinese kale. Food Chem. 131(2), 519-526. Doi: 10.1016/j. foodchem.2011.09.016

Tadiello, A., V. Ziosi, and A.S. Negri. 2016. On the role of ethylene, auxin and a golven-like peptide hormone in the regulation of peach ripening. BMC Plant Biol. 16(1), 1-17. Doi: 10.1186/s12870-016-0730-7

Tonetto De Freitas, S., C. Sautter, A.C. Silveira, and A. Brackmann. 2007. Evaluación del efecto de la aplicación de 1-MCP y la conservación en atmósfera controlada sobre la calidad poscosecha de duraznos en dos estados de madurez. Agrociencia 11(1), 67-72.

Valero, D., D. Martínez-Romero. J. Valverde. F. Guillén. S. Castillo, and M. Serrano. 2004. Could the 1-MCP treatment effectiveness in plum be affected by packaging? Postharvest Biol. Technol. 34, 295-303. Doi: 10.1016/j.postharvbio.2004.05.020

Wang, X., Y. Ding, Y. Wang, L. Pan, L. Niu, Z. Lu, G. Cui, W. Zeng, and Z. Wang. 2017. Genes involved in ethylene signal transduction in peach (Prunus persica) and their expression profiles during fruit maturation. Scientia Hortic. 224, 306-316. Doi: 10.1016/j. scienta.2017.06.035

Watkins, B.C. 2006. The use of 1-methylcyclopropene (1MCP) on fruits and vegetables. Department of Horticulture, Cornell University, Ithaca, NY. Doi: 10.1016/j. biotechadv.2006.01.005 
Yang, X., J. Song, L. Campbell-Palmer, S. Fillmore, and Z. Zhang. 2013. Effect of ethylene and 1-MCP on expression of genes involved in ethylene biosynthesis and perception during ripening of apple fruit. Postharvest Biol. Technol. 78, 55-66. Doi: 10.1016/j. postharvbio.2012.11.012
Zhang, L., L. Jiang, Y. Shi, H. Luo, R. Kang, and Z. Yu. 2012. Post-harvest 1-methylcyclopropene and ethephon treatments differently modify protein profiles of peach fruit during ripening. Food Res. Int. 48, 609619. Doi: $10.1016 /$ j.foodres.2012.05.022 